\title{
Comportamiento de Sistemas Provisionales de Protección de Borde de polietileno de alta densidad frente a cargas estáticas y de impacto
}

\section{Behaviour of Temporary Edge Protection Systems of high density polyethylene tested to static and impact load}

\author{
M. N. González (*), A. Cobo(*), C. Lozano(**), S. Bresó(**)
}

Recepción/Received: 27-XI-11

Aceptación/Accepted: 02-III-12

Publicado online/Online publishing: 25-IV-12

\section{RESUMEN}

Se han ensayado bajo cargas estáticas y dinámicas sistemas provisionales de protección de borde (SPPB) formados por una valla continua, unos fabricados con polietileno de alta densidad (HDPE) y otros con un material compuesto, añadiendo un $4 \%$ de fibra de vidrio a una matriz de HDPE.

Los ensayos, bajo cargas estáticas y de impacto, se han realizado según la norma UNE-EN 13374, para sistemas clase A y B. Se ha comprobado la influencia del envejecimiento sobre SPPB y probetas de los mismos materiales que los SPPB.

Todos los SPPB ensayados superan los requisitos de resistencia y de carga accidental y los requisitos frente a cargas dinámicas. La incorporación de fibras de vidrio da lugar a un material compuesto con un módulo de elasticidad significativamente más alto y con menor fluencia. No se aprecia dependencia de los resultados con el grado de envejecimiento ni en los SPPB ni en las probetas.

Palabras clave: polímero; refuerzo de fibras; composite; resistencia a flexión; fluencia.

\section{SUMMARY}

We have tested under static and dynamic load temporary edge protection systems (TEPS) formed by a continuous fence, some are made of high density polyethylene (HDPE) and others have been manufactured using a composite material, adding glass fiber at a matrix of HDPE at a rate of $4 \%$.

Tests under static and impact have been performed according to standard UNE-EN 13374, class systems $A$ and $B$. It has been found the influence of aging on TEPS and samples of the same materials as the TEPS.

All tested TEPS exceed the strength requirements and accidental load and requirements compared to dynamic loads. The incorporation of glass fibers results in a composite material with a modulus of elasticity higher and significantly less creep. We haven't seen dependence on the results with the degree of aging or in SPPB or in the samples.

Keywords: polymer; fiberre in forced; composite; flexural strength; creep.

\footnotetext{
(*) Universidad Politécnica de Madrid (Madrid, España).

(**) AIDICO. Instituto Tecnológico de la Construcción, Paterna (Valencia, España).
} 


\section{INTRODUCCIÓN}

El polietileno es un polímero termoplástico que combina una serie de propiedades físicas y mecánicas, como son una baja densidad y una buena relación resistencia peso, que junto a su facilidad para el procesado lo hacen idóneo en una gran variedad de aplicaciones, siendo el material plástico de mayor producción mundial $(1,2)$. Según el proceso de polimerización empleado se obtienen distintos tipos de polietileno que se caracterizan en función de su densidad. El polietileno de alta densidad (PEAD) posee generalmente valores de densidad comprendidos entre 0,94 y $0,97 \mathrm{~g} / \mathrm{cm}^{3}$, su módulo de elasticidad longitudinal es bajo, alrededor de $2.000 \mathrm{~N} / \mathrm{mm}^{2}$ y presenta altos valores de fluencia incluso para cargas muy alejadas de su límite elástico y de muy poca duración, principalmente en muestras que no presentan discontinuidades importantes en su superficie que pueden actuar como concentradores de tensiones dando lugar a un proceso de fallo frágil (3-5).

EI PEAD posee unas excelentes propiedades para ser empleado como componente de protecciones colectivas (PC), donde las acciones se producen fundamentalmente en forma de impacto. Su bajo valor de módulo de elasticidad, junto con las grandes deformaciones alcanzadas antes de la rotura, supone la posibilidad de absorber una gran cantidad de energía. Sin embargo, sus bajos módulos de elasticidad suponen en ocasiones un inconveniente, al alcanzarse en los sistemas fabricados con PEAD movimientos superiores a los admitidos por las normas que regulan el empleo de las PC. Además, el envejecimiento que se produce en ellos, debido fundamentalmente a la acción de los rayos ultravioletas del sol, hace que sus propiedades se deterioren con el tiempo (6).

La incorporación de fibras de vidrio a polímeros termoplásticos da lugar a un material compuesto en el que se pueden mejorar de manera significativa las propiedades mecánicas de origen. En particular la adición de fibra de vidrio en forma de hilos cortados a una matriz de PEAD produce un material compuesto con valores de módulo de elasticidad longitudinal y tensión de rotura superiores a los del PEAD bajo cargas estáticas $(7,8)$, menores coeficientes de fluencia (9) y mayor resistencia a impacto (10).

La norma UNE-EN 13374 "Sistemas provisionales de protección de borde. Especificaciones del producto, métodos de ensayo" (11) clasifica los SPPB en tres clases (A, B y C), en función de la inclinación de la superficie de trabajo y de la altura de caída de la persona a proteger (Figura 1). La norma indica los requisitos, en términos geométricos y mecánicos, que deben superar los SPPB en función de la clase a la que pertenecen.

\section{INTRODUCTION}

Polyethylene is a thermoplastic polymer combining a series of physical and mechanical properties such as a low density and a good strength-weight ratio, which together with the easiness to process it, becomes suitable for a great variety of applications, being plastic the mostly produced one $(1,2)$. Depending on the polymerization process employed, different types of polyurethane are obtained depending on the density. High density Polyurethane (HDPE) usually has densities in between 0.94 and $0.97 \mathrm{~g} / \mathrm{cm}^{3}$, the longitudinal elasticity is low, around $2000 \mathrm{~N} / \mathrm{mm}^{2}$ and presents high fluency values even for loads far from its elastic limit and for a short time, mainly for stress concentrators producing a fragile failure process (3-5).

HDPE has excellent properties to be used as a component in collective protections $(C P)$, where stresses are produced, mainly as impacts. The low value of the elasticity module, together with the great deformations reached before fracture, implies the possibility of absorbing a great quantity of energy. However, the low elasticity modules can be an inconvenience in certain occasions, as movements higher than the admitted by the standards regulating CP used are reached with HDPE systems. Moreover, aging performed to them, due mainly to the action of sun ultraviolet rays, deteriorates their properties with time (6).

Glass fiber incorporation to thermoplastic polymers results in a compound material, which can significantly improve the original mechanical properties. More specifically, the addition of glass fiber in cut threads to a HDPE matrix produces a compound material of longitudinal elasticity module and fracture strength higher for HDPE under static loads (7,8), lower fluency coefficients (9) and greater impact strength (10).

The UNE-EN 13374 standard, "Sistemas provisionales de protección de borde. Especificaciones del producto, métodos de ensayo" (11), classifies TEPS in three classes ( $A, B$ and $C$ ) depending on the working surface slope and on the falling height of the person to be protected (Figure 1). The standard indicates the requirements TEPS should fulfil, in geometrical and mechanical terms, depending on the class they belong to. 


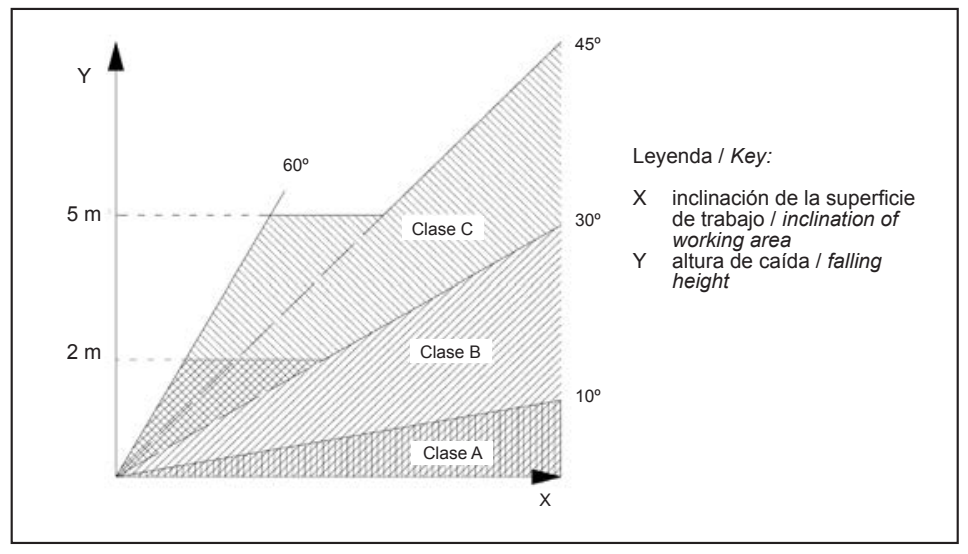

Figura 1. Clasificación de los SPPB según la norma UNE-EN 13374. Figure 1. TEPS Classification of UNE-EN 13374 standard.

Los sistemas clase A, que son los más empleados, sólo se pueden utilizar cuando el ángulo de inclinación de la superficie de trabajo es menor de $10^{\circ}$. Los sistemas clase $B$ se pueden emplear con una inclinación de la superficie de trabajo entre $10^{\circ}$ y $30^{\circ}$ o para inclinaciones de hasta $60^{\circ}$, pero con una altura de caída del cuerpo de como máximo dos metros. Los sistemas clase $\mathrm{C}$ son de aplicación con una inclinación de la superficie de trabajo entre $30^{\circ}$ y $45^{\circ}$ o hasta $60^{\circ}$ cuando la altura de caída del cuerpo se encuentra entre los 2 y los 5 metros. Para inclinaciones superiores de la superficie de trabajo y alturas que excedan los 5 metros hay que emplear otros sistemas de protección diferentes a los SPPB.

En este trabajo se han evaluado SPPB fabricados con PEAD y con un material compuesto de PEAD y fibra de vidrio. La influencia del envejecimiento se ha estudiado sobre SPPB fabricados con PEAD y sometidos a un envejecimiento natural. Los resultados se han contrastado con los obtenidos sobre probetas del mismo material que han sufrido un envejecimiento acelerado.

\section{MATERIALES Y TÉCNICAS EMPLEADAS}

Se ha trabajado sobre SPPB formados por una valla fabricada mediante inyección de PEAD con una densidad de $951 \mathrm{~kg} / \mathrm{m}^{3}$ y con un tratamiento de estabilización frente a las radiaciones ultravioletas (UV) del $4 \%$.

La valla continua se conforma con tres elementos horizontales de $150 \mathrm{~mm}$ de alto, dos elementos verticales en los extremos y elementos diagonales con espacios intermedios de $200 \mathrm{~mm}$ de ancho situados en los huecos rectangulares superior e inferior. La valla se une mediante unos anclajes integrados a los postes verticales. Los postes están separados $1.400 \mathrm{~mm}$, se han fabricado en acero S235 con sección tubular cuadrada $35 \cdot 1,5 \mathrm{~mm}$ y tienen una altura sobre el nivel de forjado de $1.080 \mathrm{~mm}$. Los
Class A systems, the most used ones, can only be used when the inclination angle of the working surface is smaIler than $10^{\circ}$. Class $B$ systems can be applied to a working surface inbetween $10^{\circ}$ and $30^{\circ}$ or for inclinations of up to $60^{\circ}$, but with a body falling height of a maximum of two metres. Class $C$ systems can be used with a working surface inclination of in between $30^{\circ}$ and $45^{\circ}$ or up to $60^{\circ}$ when the body falling height is between 2 and 5 metres. For greater inclinations of the working surface and heights exceeding 5 metres, other systems, different from the TEPS need to be employed.

This research work analyses TEPS manufactured with HDPE and with a compound material of HDPE and glass fibre. The aging influence has been studied on TEPS fabricated with HDPE and subject to natural ageing. Results have been compared to the ones obtained with test samples made with the same material, which have suffered an accelerated aging process.

\section{MATERIALS AND TESTS USED}

TEPS consisting of a fence made by a HDPE injection, with a density of $951 \mathrm{~kg} / \mathrm{m}^{3}$ and a stabilizing treatment against ultraviolet radiation (UV) of $4 \%$ have been used.

The continuous fence is composed by three horizontal elements of height $150 \mathrm{~mm}$, two vertical elements at the ends, and diagonal elements with intermediate spaces, $200 \mathrm{~mm}$ wide, placed in the rectangular voids at the top and bottom. The fence is joined through some anchors integrated within the vertical posts. The posts are separated $1400 \mathrm{~mm}$, and have been manufactured in S235 steel with square tubular section $35 \cdot 1.5 \mathrm{~mm}$ and a height above the slab level of $1080 \mathrm{~mm}$. The posts were anchored to 
postes se han anclado a una viga de hormigón armado mediante apriete tipo sargento (Figura 2). La parte interior de las mordazas, que está en contacto con la estructura soporte, tiene un tramo dentado para mejorar la adherencia del sargento con la estructura soporte.

En la Figura 3 se muestra una valla, similar a las ensayadas de material termoplástico PEAD colocada en obra.

Los resultados obtenidos sobre los sistemas anteriores, han aconsejado fabricar SPPB de la misma geometría pero añadiendo en su composición fibra de vidrio cortada en una proporción de un 4\% (PEAD+FV).

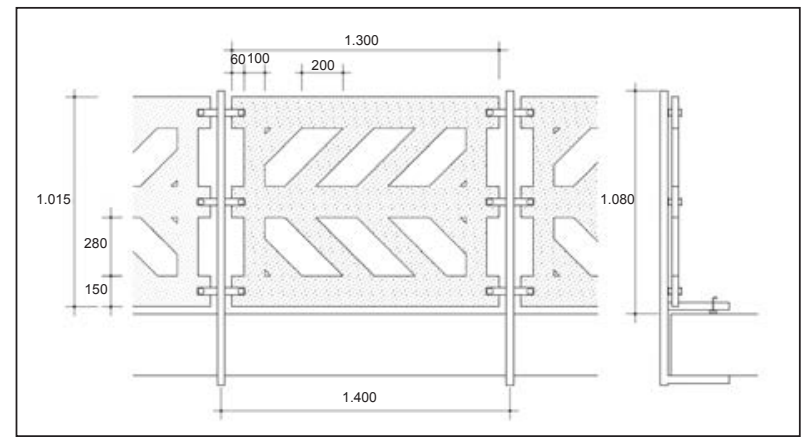

Figura 2. Geometría de los SPPB ensayados. Figure 2. Geometry of the TEPS tested.

\section{TRABAJO EXPERIMENTAL REALIZADO}

\subsection{Evaluación de SPPB frente a cargas estáticas y dinámicas}

\section{Evaluación frente a cargas estáticas}

Los sistemas se han ensayado en el Laboratorio de Elementos de Seguridad de AIDICO conforme con los requisitos establecidos en la norma UNE-EN 13374 para cargas estáticas en los SPPB clases A y B, y de conformidad con los requisitos de fuerzas dinámicas para los SPPB clase $B$.

Para evaluar la influencia del envejecimiento sobre el comportamiento mecánico frente a cargas estáticas de los SPPB fabricados en PEAD, se han realizado los ensayos sobre SPPB en estado nuevo (S1 y S4) y expuestos a un envejecimiento natural de 1 año (S2 y S5) y 2,5 años (S3 y S6) en el Centro de Prácticas Preventivas de la Fundación Laboral de la Construcción de Cuenca. La evaluación sobre sistemas PEAD+FV se ha realizado sobre elementos sin envejecer (S13 y S14).

Según la norma UNE-EN 13374, el cálculo frente a cargas estáticas debe efectuarse analizando tres situaciones: a concrete beam reinforced by a clamp (Figure 2). The inner part of the clamp jaws, which is in contact with the structure support, has a toothed stretch to improve the adhesion of the clamp with the support structure.

Figure 3 shows a fence, similar to the tested HDPE thermoplastic material placed in the work site.

The results obtained with earlier systems, have advised testing the same TEPS geometry but adding to their composition cut glass fiber in a 4 per cent ratio (HDPE+GF).

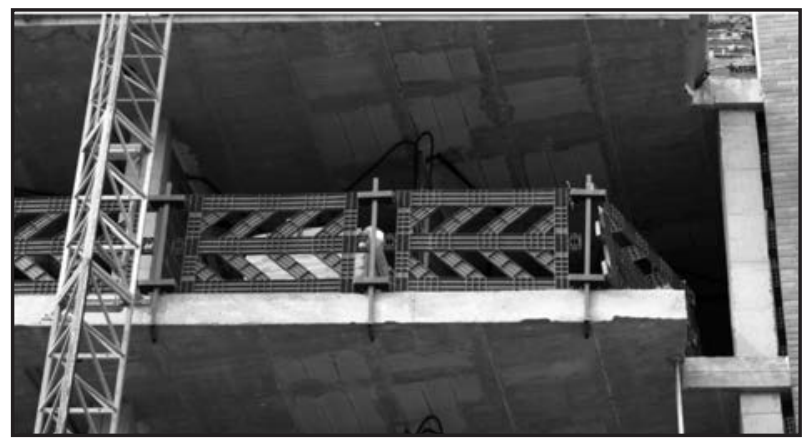

Figura 3. Fotografía de SPPB con materiales termoplásticos PEAD.

Figure 3. TEPS picture with HDPE thermoplastic materials.

\section{TESTING PERFORMED}

\subsection{Assessment of TEPS regarding static and dynamic loads}

\section{Assessment regarding static loads}

The systems have been tested at AIDICO, laboratory of safety elements complying with the requirements established in the UNE-EN 13374 standard for static loads in classes $A$ and $B$ TEPS, and in accordance with the requirements of dynamic forces for class $B$ TEPS.

To assess the influence of ageing on the mechanical behaviour, for the static loads in TEPS manufactured in HDPE, tests of TEPS have been performed in new state ( $S 1$ and S4) and exposed to 1 year (S2 and S5) natural ageing, and to 2.5 years (S3 and S6) natural ageing at the Centre of Preventive Practices of the Construction Labour Foundation of Cuenca. HDPE+GF systems assessment has been done on elements without being aged (S13 and S14).

According to UNE-EN 13374 standard, calculation for static loads must be carried out by analyzing three situations: 
Estado Límite Último (ELU), Estado Límite de Servicio (ELS) y carga accidental.

En ELU se comprueba que cada protección de borde y cada uno de sus componentes, excepto los plintos, deben estar diseñados para resistir una carga aplicada perpendicularmente al plano del SPPB, $F_{\text {máx }}$ que en el caso de elementos de material termoplástico toma el valor de $0,50 \mathrm{kN}$ en cualquier punto del sistema excepto en el rodapié, donde la carga es de 0,33 kN. La carga debe aplicarse en diez incrementos regulares y mantenerse durante un minuto, midiéndose la flecha de la protección de borde, $\delta_{\text {máx }}$ bajo la carga máxima. A continuación se descarga el sistema y se mide la flecha residual, $\delta_{\text {res }}$. Finalmente, el sistema debe ser cargado con un esquema de cargas idéntico, incrementándose hasta la carga de rotura, $\mathrm{R}_{\mathrm{u}}$ que provoca un fallo notable a nivel del conjunto del sistema o en uno de los elementos que lo componen. El ensayo se considera válido cuando se cumplen simultáneamente las tres condiciones siguientes: bajo la carga máxima no se producen plastificaciones o roturas, la flecha residual es inferior al $10 \%$ de la flecha bajo la carga máxima, y $R_{u}$ es superior a 1,2 veces la máxima carga de ensayo. La comprobación en ELU equivale a la evaluación de requisitos de resistencia de SPPB.

Para superar el ELS, la flecha del sistema no debe ser mayor de $55 \mathrm{~mm}$ cuando se aplica la fuerza $\mathrm{F}_{\mathrm{T} 1}$ de $0,30 \mathrm{kN}$ en cualquier punto excepto en el rodapié, donde la fuerza a aplicar, $\mathrm{F}_{\mathrm{T} 2}$, es de $0,20 \mathrm{kN}$. Una vez alcanzada la carga de ensayo, debe mantenerse durante un minuto con el objeto de determinar las características de fluencia del sistema. La comprobación en ELS equivale a la evaluación de requisitos de desplazamiento.

Experimentalmente la comprobación en ELS y en ELU se realiza aplicando acciones horizontales según el ciclo de carga que se expone a continuación. Se aplica una carga inicial de $0,10 \mathrm{kN}$ al sistema. Esta carga se mantiene durante un minuto $\mathrm{y}$, a continuación se descarga el sistema, quedando éste con un desplazamiento residual que constituye la flecha de referencia, $\delta_{1}$. A continuación se aplica la carga del ensayo correspondiente, se mantiene un minuto y se descarga.

En cuanto al estudio de las cargas accidentales, se indica que la barandilla principal, la barandilla intermedia y el plinto, deben resistir una carga puntual gravitatoria $F_{D}$ $=1,25 \mathrm{kN}$. Esta carga debe aplicarse en la posición más desfavorable del SPPB, dentro de un sector inclinado \pm $10^{\circ}$ respecto de la vertical.

La evaluación frente a cargas estáticas se ha realizado aplicando la carga en el punto superior central del SPPB, que se corresponde con la situación que provoca los efectos más desfavorables.
Ultimate Limit State (ULS), Service Limit State (SLS) and accidental load.

Testing ULS for each edge protection and for each of its components, except for the plinths, proved that they should be designed to withstand a load applied perpendi-

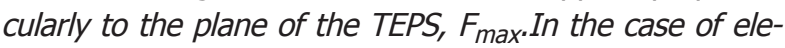
ments of thermoplastic material, this load has the value of $0.50 \mathrm{kN}$ at any point in the system except for the skirting board, where the load is $0.33 \mathrm{kN}$. The load was applied in ten regular increments and maintained for one minute, measuring the deflection of the edge protection, $\delta_{\max }$ under maximum load. Then, the system was unloaded and residual deflection, $\delta_{\text {res }}$ measured. Finally, the system was reloaded with an identical load scheme, increasing it until reaching the fracture load $R_{u}$, which caused a notable failure of the whole system or one of its elements. The test is considered valid when the three following conditions are simultaneously met: no plasticizing nor cracks occur under the maximum load, the residual deflection is less than $10 \%$ of the deflection under the maximum load and $R_{U}$ is greater than 1.2 times the maximum test load. Testing the ULS equals the assessment of the TEPS strength requirements.

To exceed the ULS, the deflection of the system should not be larger than $55 \mathrm{~mm}$, when applying a FT1 load of $0.30 \mathrm{kN}$ anywhere except at the skirting board, where the load to be applied, FT2, is $0.20 \mathrm{kN}$. Once the test load is reached, it must be maintained for one minute in order to determine the characteristics of the yield system. Testing the ULS equals the displacement requirements assessment.

Experimentally, in LSU and SLS testing is carried out by applying horizontal stresses following the load cycle outlined below. An initial load of $0.10 \mathrm{kN}$ is applied to the system. This load is maintained for one minute and then the system is unloaded, leaving a residual displacement, which constitutes the reference deflection, $\delta_{1}$. Then, the corresponding test load is applied, maintaining it for a minute and then unloaded.

Regarding the study of accidental loads, it is stated that the main handrail, the middle handrail and the plinth should resist a gravitational specific load $F D=1.25 \mathrm{kN}$. This load must be applied in the most unfavourable position of the TEPS, within an inclined sector of $\pm 10^{\circ}$ in relation to the vertical.

The assessment of static loads has been performed applying the load at the upper central point of TEPS, which corresponds to the situation that causes the most unfavourable effects. 


\section{Evaluación frente a cargas dinámicas}

La evaluación frente a cargas dinámicas se ha realizado sobre SPPB PEAD nuevos (S7 y S8), envejecidos durante 1 año (S9 y S10), envejecidos durante 2,5 años (S11 y S12) y sobre SPPB PEAD+FV (S13 y S14).

Para esta evaluación, la norma establece que el SPPB debe ser capaz de absorber una energía cinética de $1.100 \mathrm{~J}$ en cualquier punto de la protección situado a una altura de $200 \mathrm{~mm}$ por encima de la superficie de trabajo, y de 500 $\mathrm{J}$ en cualquier parte a mayor altura. El ensayo se realiza mediante el impacto por caída pendular de un saco esferocónico de $500 \mathrm{~N}$ que cae desde una altura de 2,25 m cuando se requiere absorber una energía cinética de 1.100 $\mathrm{J}$, y desde una altura de 1,00 m para una energía cinética de $500 \mathrm{~J}$ (Figura 4). La geometría del saco y su composición vienen definidos en la norma UNE-EN 596 (12).

La protección de borde supera los requisitos de la norma cuando el saco queda retenido por el sistema.

Para los dos tipos de impacto, se han escogido como puntos más desfavorables las secciones centrales superior $(E=500 \mathrm{~J})$ e inferior $(E=1.100 \mathrm{~J})$.

\section{Assessment of dynamic loads}

The assessment of dynamic loads has been performed on new HDPE TEPS (S7 and S8), aged 1 year (S9 and S10), aged 2.5 years (S11 and S12) and on HDPE+GF TEPS(S13 and S14).

For this evaluation, the standard establishes TEPS should be able to absorb a kinetic energy of $1100 \mathrm{~J}$ at any point of the protection, located at a height of $200 \mathrm{~mm}$ above the working surface, and of $500 \mathrm{~J}$ anywhere at a higher height. Testing has been done by impacting a sphereconical bag at a pendular fall of $500 \mathrm{~N}$, falling from a $2.25 \mathrm{~m}$ height when the system is required to absorb a kinetic energy of $1100 \mathrm{~J}$, and from a height of $1.00 \mathrm{~m}$ for a kinetic energy of $500 \mathrm{~J}$ (Figure 4). The geometry of the bag and its composition are defined in the UNE-EN 596 standard (12).

The edge protection meets the requirements of the standard when the bag is retained by the system.

For the two types of impact, central upper section ( $E=$ $500 \mathrm{~J})$ and central bottom section ( $E=1100 \mathrm{~J}$ ) have been chosen as the most unfavourable points.

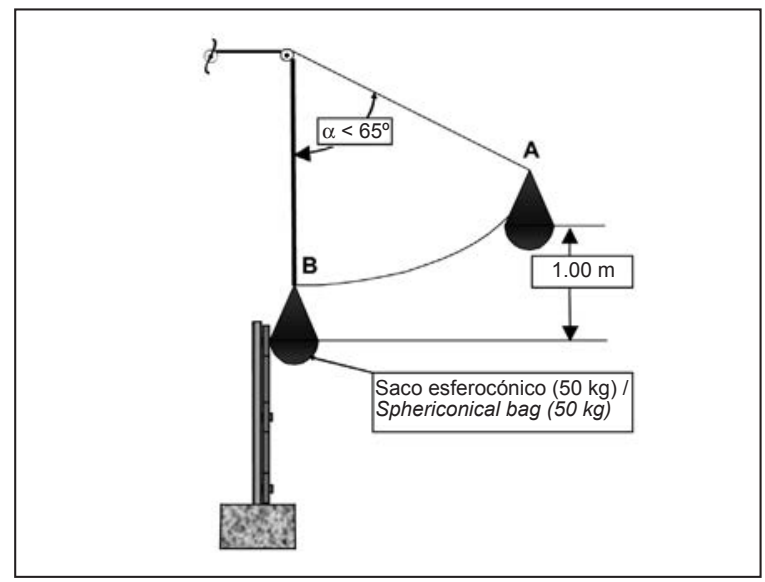

Figura 4. Ensayo frente a cargas dinámicas para una energía de $500 \mathrm{~J}$ en la parte superior del SPPB.

Figure 4. Test to comply with dynamic load requirements for $500 \mathrm{~J}$ energy on the highest part of the edge protection.

\subsection{Ensayos realizados sobre probetas de material termoplástico PEAD}

Se han preparado probetas de plástico de sección rectangular de $2 \mathrm{~mm}$ de altura y anchos de 8 y $10 \mathrm{~mm}$, con una longitud de $50 \mathrm{~mm}$. Parte de las probetas se han sometido a un ciclo de envejecimiento acelerado según UNE-EN ISO 4892-2 (13) en cámara climática con fuente de energía luminosa (arco de xenón) hasta conseguir períodos equivalentes de envejecimiento de 1.000, 1.500, 2.000, 3.000 y $4.000 \mathrm{~h}$. El resto de probetas se han ensayado sin envejecer con el objeto de servir de patrón de comparación.

\subsection{Tests performed on HDPE thermoplastic material samples}

Samples of plastic rectangular section, $2 \mathrm{~mm}$ in height and widths of 8 to $10 \mathrm{~mm}$ with a length of $50 \mathrm{~mm}$ have been prepared. Part of the samples have been subjected to an accelerated cycle of aging according to UNE-EN ISO 4892-2 (13) standard, in a climatic chamber with light energy source (xenon arc) to achieve equivalent periods of ageing of 1000, 1500, 2000, 3000 and $4000 \mathrm{~h}$. The other samples have been tested without aging to be used as a comparison reference. 
Los ensayos de flexión estática se han realizado según la norma UNE-EN ISO 178 (14), disponiendo las probetas de $10 \mathrm{~mm}$ de ancho con una distancia entre apoyos de 32 $\mathrm{mm}$. El control del ensayo ha sido por carrera, con una velocidad de $1 \mathrm{~mm} / \mathrm{min}$. El módulo de elasticidad se ha obtenido según la expresión [1].
Static bending tests have been made according to UNE-EN ISO 178 standard (14), and the samples were $10 \mathrm{~mm}$ in width with a distance between supports of $32 \mathrm{~mm}$. Control of the tests has been by race, with a speed of $1 \mathrm{~mm} / \mathrm{min}$. The elasticity modulus has been obtained according to the expression [1].

$$
E=\frac{L^{3}}{4 b h^{3}}\left(\frac{\Delta F}{\Delta s}\right)
$$

Donde

E: módulo de elasticidad longitudinal $\left(\mathrm{N} / \mathrm{mm}^{2}\right)$.

L: distancia entre apoyos ( $\mathrm{mm})$.

h: espesor de la probeta ( $\mathrm{mm})$.

b: anchura de la probeta $(\mathrm{mm})$.

$\Delta \mathrm{s}$ : diferencia de las flechas $\mathrm{s}_{2}-\mathrm{s}_{1}$. Siendo $\mathrm{s}_{2}$ la flecha correspondiente a una deformación del $0,25 \%$ y $s_{1}$ la flecha correspondiente a una deformación del 0,05\%.

$\Delta \mathrm{F}$ : diferencia entre las cargas correspondientes a las flechas $s_{2}$ y $s_{1}$.

Los ensayos de impacto se han realizado según la norma UNE-EN ISO 179-1 (15), sometiendo las probetas de 8 $\mathrm{mm}$ de ancho a un impacto con una energía de $2 \mathrm{~J}$ y una velocidad de 2,9 m/s. La entalla producida ha sido del tipo A, con una profundidad de $2 \mathrm{~mm}$. El impacto se ha producido sobre la cara estrecha no entallada.

\section{RESULTADOS OBTENIDOS}

\subsection{Comportamiento de SPPB fabricados en material termoplástico PEAD}

\section{Comportamiento frente a cargas estáticas}

A continuación se indican los resultados obtenidos en cada uno de los SPPB y para las configuraciones descritas, cuando la carga se aplica en un área de $100 \times 100$ mm sobre la parte superior de la misma, a $1 \mathrm{~m}$ de altura.

\section{Requisito de desplazamiento}

En la Tabla 1 se muestran los resultados obtenidos sobre SPPB nuevos y envejecidos de forma natural durante 1 año y 2,5 años. Para la carga de ensayo se indican la flecha de referencia $\left(\delta_{1}\right)$, el máximo desplazamiento alcanzado $\left(\delta_{2}\right)$ y la flecha del SPPB $\left(\delta_{3}\right)$ obtenida como diferencia entre los dos valores anteriores.

En el gráfico de la Figura 5 se muestra el comportamiento de los cuatro SPPB durante la realización del ensayo de flecha. En la Figura 6 se ofrece una fotografía de la realización del ensayo.
Where

\author{
E: longitudinal elasticity modulus $\left(\mathrm{N} / \mathrm{mm}^{2}\right)$. \\ L: distance between supports $(\mathrm{mm})$. \\ h: sample thickness ( $\mathrm{mm})$. \\ b: sample width ( $\mathrm{mm}$ ).
}

$\Delta s$ : deflection difference $s_{2}-s_{1}$. Where $s_{2}$ is the deflection corresponding to a deformation of $0.25 \%$ and $s_{1}$ deflection corresponding to $0.05 \%$ deformation.

$\Delta F$ : difference between loads corresponding to $s_{2}$ and $s_{1}$ deflections.

Impact tests have been performed according to UNEEN ISO 179-1 standard (15) subjecting the $8 \mathrm{~mm}$ wide samples to a $2 \mathrm{~J}$ energy impact and a speed of $2.9 \mathrm{~m} / \mathrm{s}$. the groove produced has been of type $A$, with a depth of $2 \mathrm{~mm}$. The impact has been on the narrow face not grooved.

\section{RESULTS OBTAINED}

\subsection{Performance of TEPS manufactures with HDPE thermoplastic material}

\section{Behavior to static loads}

Below are the results obtained in each of the TEPS and the described settings, when the load is applied over an area of $100 \times 100 \mathrm{~mm}$ on the upper part, at $1 \mathrm{~m}$ height.

\section{Displacement requirement}

Table 1 shows the results on new TEPS, and TEPS aged naturally during 1 year and 2.5 years. For the test load $\left(\delta_{1}\right)$, the reference deflection is specified, the maximum displacement reached $\left(\delta_{2}\right)$ and the deflection of TEPS $\left(\delta_{3}\right)$ obtained as the difference between the two previous values.

Graph in Figure 5 shows the behavior of the four TEPS during the deflection test. Figure 6 provides a picture of the test. 
Tabla 1 / Table 1

Resultados de la evaluación del requisito de desplazamiento. Evaluation results of the displacement requirement.

\begin{tabular}{|c|c|c|c|c|}
\hline SPPB PEAD y PEAD+FV / TEPS HDPE and HDPE+FV & $F_{\text {máx }}(k N)$ & $\delta_{1}(\mathrm{~mm})$ & $\delta_{1}(\mathrm{~mm})$ & $\delta_{1}(\mathrm{~mm})$ \\
\hline PEAD nuevo (S1) / newHDPE (S1) & 0.30 & 11.13 & 109.36 & 98.23 \\
\hline PEAD envejecido un año (S2) / HDPE aged one year (S2) & 0.30 & 16.48 & 110.79 & 94.31 \\
\hline PEAD envejecido 2,5 años (S3) / HDPE aged 2.5 years (S3) & 0.30 & 16.67 & 115.91 & 99.24 \\
\hline PEAD+FV nuevo (S13) / HDPE+FV new (S13) & 0.30 & 2.93 & 46.63 & 43.70 \\
\hline
\end{tabular}

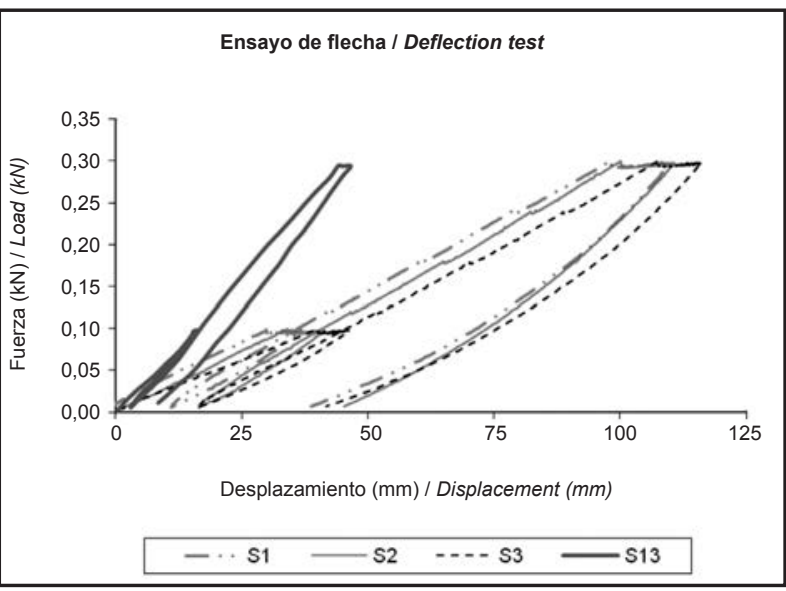

Figura 5. Comportamiento carga-desplazamiento durante la evaluación del ensayo de flecha. Carga aplicada en el punto central superior de los sistemas.

Figure 5. Load-displacement behavior during the evaluation of displacement test. Load applied to the highest central point of the systems.

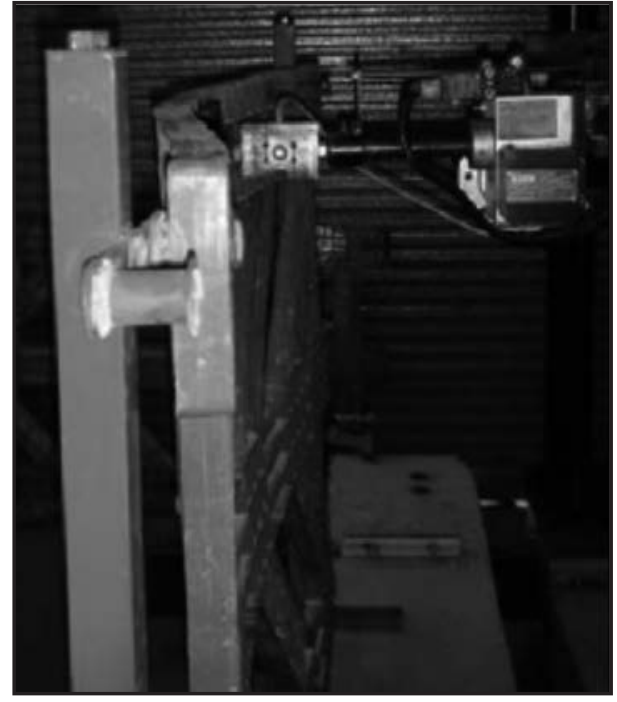

Figura 6. Realización del ensayo de flecha. Figure 6. Deflection test.

\section{Requisito de resistencia}

En la Tabla 2 se incluyen los resultados correspondientes al ensayo de resistencia sobre cuatro SPPB similares a los anteriores cundo la carga se aplica en el punto central de la parte superior de los sistemas. $F_{\text {máx }}$ es la máxima carga de ensayo; $\delta_{1}$ la flecha de referencia; $\delta_{2}$ el máximo desplazamiento; $\delta_{\text {máx }}$ la flecha del ensayo; y $\delta_{\text {res }}$ la flecha residual.

En la Figura 7 se muestra el comportamiento de los cuatro sistemas durante el ensayo de resistencia.

\section{Strength requirement}

Table 2 includes the results corresponding to the strength test on four TEPS similar to the previous ones, when the load is applied at the central point of the upper part of the systems. $F_{\text {max }}$ is the maximum test load; $\delta_{1}$ the reference deflection; $\delta_{2}$ the maximum displacement; $\delta_{\max }$ the test deflection; and $\delta_{\text {res }}$ the residual deflection.

Figure 7 shows the behaviour of the four systems during the strength systems

Tabla 2 / Table 2

Resultados de la evaluación del requisito de resistencia. Results of the evaluation of strength requirement.

\begin{tabular}{|c|c|c|c|c|c|}
\hline SPPB PEAD y PEAD+FV / TEPS HDPE and HDPE+FV & Fmáx (kN) & $\mathbf{\delta 1}(\mathbf{m m})$ & $\mathbf{\delta} 2(\mathbf{m m})$ & $\mathbf{\delta m a ́ x ~ ( m m ) ~}$ & ठres (mm) \\
\hline PEAD nuevo (S4) / new HDPE (S4) & 0.50 & 9.56 & 156.87 & 148.31 & 56.38 \\
\hline PEAD envejecido un año (S5) / HDPE aged one year (S5) & 0.50 & 13.95 & 168.21 & 154.26 & 72.02 \\
\hline PEAD envejecido 2,5 años (S6) /HDPE aged 2.5 years (S6) & 0.50 & 20.58 & 176.47 & 155.89 & 75.40 \\
\hline PEAD+FV nuevo (S14) / HDPE+FV new (S14) & 0.50 & 2.57 & 84.37 & 81.80 & 8.03 \\
\hline
\end{tabular}




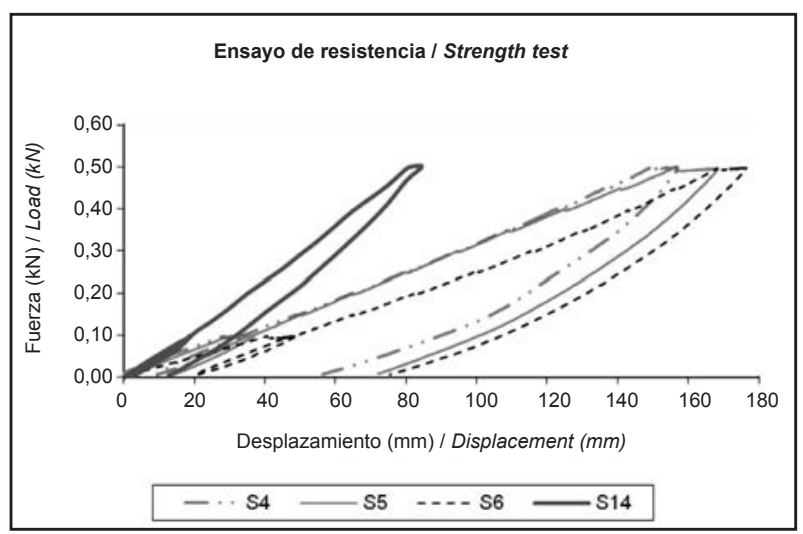

Figura 7. Comportamiento carga-desplazamiento durante la evaluación del ensayo de resistencia. Carga aplicada en el punto central superior de los sistemas.

Figure 7. Load-displacement behavior during the evaluation of strength test. Load applied to the highest central point of the systems.

\section{Comportamiento frente a cargas dinámicas}

Todos los SPPB han superado los requisitos de la norma UNE-EN 13374 frente a cargas dinámicas para sistemas clase B. Tanto los SPPB PEAD nuevos como los envejecidas durante 1 año y 2,5 años y los sistemas PEAD+FV absorben la energía del impacto de $500 \mathrm{~J}$ en la parte superior y del impacto de $1.100 \mathrm{~J}$ en su parte inferior.

\subsection{Comportamiento de probetas de material termoplástico PEAD}

En la Tabla 3 se muestran los resultados de los ensayos estáticos y dinámicos sobre probetas de material termoplástico nuevas y envejecidas aceleradamente durante 1.000 h, 1.500 h, 2.000 h, 3.000 h y 4.000 h. Los datos correspondientes a cada uno de los grados de envejecimiento se han obtenido realizando la media de los valores obtenidos sobre dos probetas. Para el ensayo estático de flexión se indican los valores de módulo de elasticidad longitudinal $\mathrm{E}$, tensión de rotura $\sigma_{\mathrm{R}}$ y flecha correspondiente a la carga máxima $\mathrm{f}_{1}$. Para el ensayo dinámico, se indica para todas las probetas su resistencia al impacto RI.

\section{Behavior to dynamic loads}

All TEPS meet the requirements of the UNE-EN 13374 standard stated for dynamic loads for class B systems. Both the new HDPE TEPS aged during 1 year and 2.5 years and the HDPE+GF systems absorb the energy of the impact of $500 \mathrm{~J}$ at the top, and the impact of 1100 (J) on the bottom.

\subsection{Behavior of HDPE thermoplastic material samples}

Table 3 shows the results of the static and dynamic tests on samples of thermoplastic material new and aged rapidly during $1000 h, 1500 h, 2000 h, 3000 h$ and $4000 h$. Data for each of the ageing degrees have been obtained by finding the mean of the values obtained on two test samples. For the static bending test the following values are indicated: longitudinal elasticity module $E$, fracture strength $\sigma_{R}$ and deflection corresponding to the maximum load $f_{1}$. For the dynamic test, the impact strength $R I$ is indicated for all test samples.

Tabla 3 / Table 3

Resultados de los ensayos estáticos y de impacto sobre probetas de plástico. Results of static and impact tests on plastic samples.

\begin{tabular}{|c|c|c|c|c|}
\hline & $\mathbf{E}\left(\mathbf{N} / \mathbf{m m}^{2}\right)$ & $\sigma \mathbf{R}\left(\mathbf{N} / \mathbf{m m}^{2}\right)$ & $\mathbf{f 1}(\mathbf{m m})$ & $\mathbf{R I}\left(\mathbf{k J} / \mathbf{m}^{2}\right)$ \\
\hline 0 & 2010 & 51.5 & 5.2 & 9.6 \\
\hline $1000 \mathrm{~h}$ & 1830 & 52.4 & 5.1 & 9.4 \\
\hline $1500 \mathrm{~h}$ & 1820 & 52.0 & 5.3 & 8.8 \\
\hline $2000 \mathrm{~h}$ & 2020 & 51.4 & 5.1 & 8.9 \\
\hline $3000 \mathrm{~h}$ & 1900 & 51.5 & 5.1 & 8.7 \\
\hline $4000 \mathrm{~h}$ & 2050 & 52.5 & & 9.6 \\
\hline
\end{tabular}


En la Figura 8 se muestran los diagramas carga-desplazamiento de las probetas ensayadas a flexión estática.
Figure 8 shows the load-displacement diagrams of the samples tested to static bending.

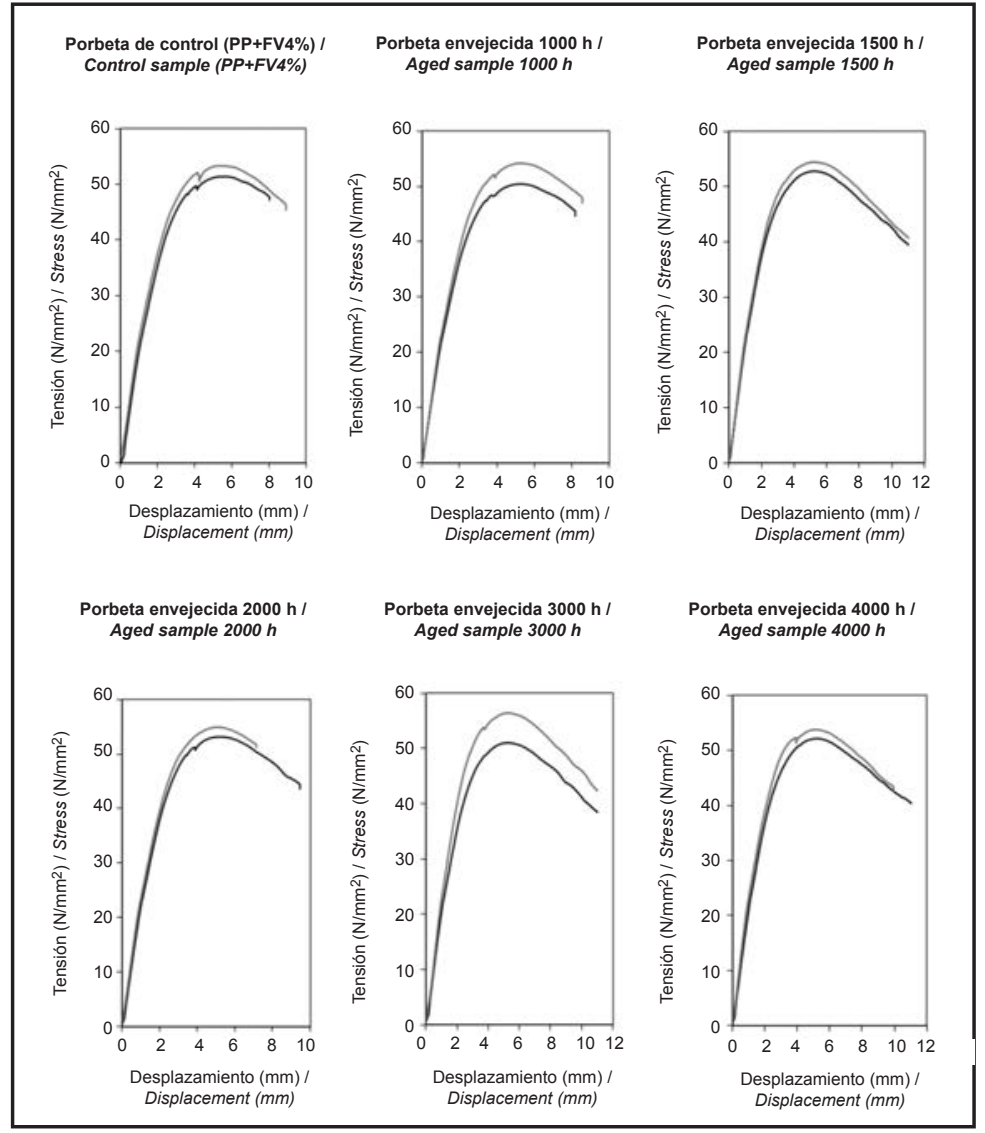

Figura 8. Diagrama carga-desplazamiento de las probetas ensayadas a flexión estática. Figure 8. Load-displacement diagram of the samples tested to static bending.

\section{ANÁLISIS Y DISCUSIÓN DE RESULTADOS}

\subsection{Resultados obtenidos sobre SPPB}

\section{Ensayos estáticos}

Requisito de desplazamiento

Los resultados obtenidos en el ensayo de flecha sobre SPPB (Tabla 1 y Figura 5) indican que los desplazamientos alcanzados por los SPPB PEAD son muy superiores, en más del doble, a los de los SPPB PEAD+FV. Los valores de desplazamiento alcanzados (Tabla 1) junto con la comparación de las pendientes de las gráficas carga-desplazamiento de los SPPB PEAD+FV con las de los SPPB PEAD (Figura 5) constatan que la adición de fibra de vidrio al PEAD da lugar a un material compuesto con valores de módulo de elasticidad longitudinal muy superiores a los del material base.

\section{ANALYSIS AND RESULTS DISCUSSION}

\subsection{Results obtained on TEPS}

\section{Static tests}

Displacement requirement

Results obtained in the deflection test on TEPS (Table 1 and Figure 5) indicate that displacements achieved by the HDPE TEPS are much greater, even more than double, to the displacements of HDPE+GF TEPS. Achieved displacement values (Table 1) along with the curve comparing the load-displacement graphic of HDPE+GF TEPS, with the one of the SPPB HDPE (Figure 5) show that the addition of glass-fiber to HDPE causes a compound material with a longitudinal elasticity modulus of values much higher than the base material. 
Tabla 4 / Table 4

Flechas instantáneas, totales y diferidas de los sistemas S1, S2, S3 y S13 cuando se mantienen durante 1 minuto las cargas 0,10 kN y $0,30 \mathrm{kN}$.

Instantaneous deflection and total displacements of the systems S1, S2, S3 and S13 when loads of $0.10 \mathrm{kN}$ and $0.30 \mathrm{kN}$ are maintained for 1 minute.

\begin{tabular}{|c|c|c|c|c|c|c|c|c|c|}
\hline & \multicolumn{4}{|c|}{$\mathbf{0 . 1 0} \mathbf{~ k N}$} & & \multicolumn{4}{c|}{$\mathbf{0 . 3 0} \mathbf{~ k N}$} \\
\cline { 2 - 11 } & $\mathbf{f}_{\mathbf{i}}(\mathbf{m m})$ & $\mathbf{f}_{\mathbf{t}}(\mathbf{m m})$ & $\mathbf{f}_{\mathbf{d}}(\mathbf{m m})$ & $\mathbf{\%}$ & & $\mathbf{f}_{\mathbf{i}}(\mathbf{m m})$ & $\mathbf{f}_{\mathbf{t}}(\mathbf{m m})$ & $\mathbf{f}_{\mathbf{d}}(\mathbf{m m})$ & $\%$ \\
\hline $\mathrm{S} 1$ & 30.99 & 36.84 & 5.85 & 18.9 & & 87.52 & 98.23 & 10.71 & 12.2 \\
\hline $\mathrm{S} 2$ & 35.09 & 41.35 & 6.26 & 17.8 & & 83.91 & 94.31 & 10.40 & 12.4 \\
\hline $\mathrm{S} 3$ & 41.20 & 46.21 & 5.01 & 12.2 & & 90.99 & 99.24 & 8.25 & 9.1 \\
\hline $\mathrm{S} 13$ & 15.43 & 16.33 & 0.9 & 5.8 & & 41.20 & 43.70 & 2.50 & 6.1 \\
\hline
\end{tabular}

En los tres SPPB PEAD ensayados, los desplazamientos son muy similares y además no se aprecia una relación entre el valor del desplazamiento obtenido y el grado de envejecimiento del sistema, por lo que se podría afirmar que el grado de envejecimiento no influye en el desplazamiento de SPPB de estas características.

En la Figura 5 se puede apreciar que el comportamiento de los tres sistemas es muy lineal y poco elástico, independientemente del grado de envejecimiento del sistema y de la posible adición de fibras de vidrio.

En la Tabla 4 se muestran los valores de flecha diferida de los cuatro SPPB para las cargas de $0,10 \mathrm{kN}$ y $0,30 \mathrm{kN}$, cuando éstas se mantienen aplicadas durante 1 minuto.

El análisis de los valores de la Tabla permite comprobar que las flechas diferidas de los tres SPPB PEAD alcanzan valores muy altos, incluso para cargas tan pequeñas como $0,10 \mathrm{kN}$ mantenidas por períodos de tiempo tan pequeños como un minuto. También se puede apreciar que en los tres sistemas la flecha diferida, medida en tanto por ciento respecto de la inicial, es menor con la carga de $0,30 \mathrm{kN}$ que con la carga de 0,10 kN, lo cual indica que la flecha diferida no se incrementa con el nivel de carga, como es usual con sistemas fabricados con otros materiales, sino que disminuye. Además para los dos valores de carga analizados, no existe ninguna relación entre el grado de envejecimiento y la flecha diferida. Para el SPPB PEAD+FV la flecha diferida es mucho menor que la alcanzada en los SPPB PEAD, tanto en valores absolutos como en valores relativos. En este caso se mantiene la misma relación de flecha diferida respecto de la inicial con cargas de $0,10 \mathrm{kN}$ y de $0,30 \mathrm{kN}$.

Requisito de resistencia

La Tabla 2 y la Figura 7 muestran los resultados de los ensayos de resistencia sobre los cuatro sistemas ensayados. Se cumplen los requisitos de la norma: se alcanza la máxima carga de ensayo y la flecha residual es inferior al $10 \%$ del máximo desplazamiento alcanzado. Los sistemas se han cargado hasta 0,60 kN, condición de resistencia última, sin observarse ni roturas ni plastificaciones.
In the three tested HDPE TEPS, displacements are very similar and, in addition, no relationship between the value of the displacement obtained and the aging degree of the system is observed, so it could be stated that the degree of ageing does not affect the displacement of TEPS with these features.

In Figure 5, it can be seen that the behavior of the three systems is linear and little elastic, regardless of the aging degree of the system and the possible addition of glassfibers.

Table 4 shows the deflection values of the four TEPS tested, for $0.10 \mathrm{kN}$ and $0.30 \mathrm{kN}$ loads when they are maintained for one minute.

Analysis of the values of the Table allows stating that deferred deflections of the three HDPE TEPS reach very high values, even for very small loads such as $0.10 \mathrm{kN}$, held maintained for time periods as small as one minute. In the three systems, the deferred deflection, measured as percentage regarding the initial one, is smaller with the $0.30 \mathrm{kN}$ load than with the $0.10 \mathrm{kN}$ load, which indicates that the deferred deflection does not increase with the load level amount, as it normally happens with systems made with other materials. On the contrary, it decreases. In addition, in the two analyzed load values, there is no relationship between the ageing degree and the deferred deflection. For HDPE+GF TEPS the deferred deflection is much smaller than the one reached with the HDPE TEPS, both in absolute and relative values. In this case, the same relationship between the deferred deflection and the initial one with loads of $0.10 \mathrm{kN}$ and $0.30 \mathrm{kN}$ is maintained.

\section{Strength requirement}

Table 2 and Figure 7 show the results of the strength tests on the four analyzed systems. They meet the standard requirements: the maximum test load is reached and the residual deflection is less than $10 \%$ of the maximum displacement achieved. Systems have been loaded up to $0.60 \mathrm{kN}$, ultimate strength condition, without fractures or plasticizings being produced. 
En la Figura 7 se puede comprobar que el comportamiento de los cuatro sistemas es muy lineal y muy similar al obtenido en el ensayo de desplazamiento. De nuevo se pone de manifiesto la gran diferencia de la rigidez de los SPPB PEAD+FV frente a los PEAD por la pendiente de las gráficas de comportamiento. El desplazamiento residual alcanzado en los tres sistemas PEAD es muy alto pero debido a los enormes valores de desplazamiento máximo obtenidos, el desplazamiento residual permanece muy por debajo del desplazamiento máximo (Tabla 2).

\section{Ensayos dinámicos}

Los enormes desplazamientos que son capaces de admitir estos sistemas antes del fallo les confieren una gran posibilidad de absorber energía lo que se traduce en el excelente comportamiento frente a carga de impacto. Tanto los SPPB PEAD nuevos (S7 y S8) y envejecidos (S9, S10, S11 y S12) como los SPPB PEAD+FV (S13 y S14) han retenido el saco cuando ha impactado con energías de 500 J y 1100 J, manteniendo los sistemas totalmente su integridad.

\subsection{Resultados obtenidos sobre probetas de plástico}

Los resultados obtenidos en los ensayos de flexión estática sobre probetas de PEAD sometidas a distintos niveles de envejecimiento muestran que no existe una degradación en las propiedades mecánicas del material debido al envejecimiento del mismo. Tanto el módulo de elasticidad como la tensión de rotura y el desplazamiento bajo carga máxima no dependen de la edad de envejecimiento de la muestra ensayada. Los valores de las energías absorbidas en los ensayos hasta la carga máxima o hasta el desplazamiento último tampoco se ven afectados por el envejecimiento de las probetas.

El análisis de los resultados sobre los ensayos dinámicos arrojan las mismas conclusiones que los obtenidos sobre los ensayos estáticos: no existe una relación entre el grado de envejecimiento y la resistencia al impacto de las muestras ensayadas.

\subsection{Consideraciones respecto al requisito de desplazamiento}

Prácticamente todas las normas internacionales consultadas que regulan los SPPB especifican los requisitos constructivos, geométricos y mecánicos que deben cumplir. Sin embargo, el formato de comprobación de los requisitos mecánicos varía significativamente entre los distintos documentos consultados y da lugar a soluciones muy distintas (16-18).

Parece apropiado limitar el máximo desplazamiento de un sistema bajo un determinado valor de carga. Esta
Figure 7, shows the behavior of the four systems and it can be noticed, that it is very linear and very similar to the one obtained in the displacement test. Again, the great difference in rigidity of the HDPE+GF TEPS as opposed to the HDPE can be seen in the behavior curves of the graphs. Residual displacement attained in three HDPE systems is very high, but because of the enormous maximum displacement values obtained, residual displacement remains well below the maximum displacement (Table 2).

\section{Dynamic tests}

The great displacements that these systems are able to support, before fracture, give them a great possibility to absorb energy, which turns into an excellent behaviour to impact load. Both the new HDPE TEPS (S7 and S8) and aged (S9, S10, S11 and S12) as the HDPE+GF TEPS (S13 and S14) have retained the bag when energies of $500 \mathrm{~J}$ with $1100 \mathrm{~J}$ have impacted, and the systems maintain their full integrity.

\subsection{Results obtained in plastic samples}

Results from static bending tests on HDPE samples subjected to different aging levels show that there is no degradation in the mechanical properties of the material due to the aging. Both the modulus of elasticity and the fracture stress and displacement under maximum load does not depend on the age of the sample being tested. The values of the absorbed energy in the tests to the maximum load or ultimate displacement are not affected by the ageing of the test samples.

The analysis of the results on dynamic testing show the same conclusions, as those obtained on static testing: there is a relationship between the degree of ageing and the resistance to the impact of the tested samples.

\subsection{Considerations to displacement requirement}

Virtually all the international standards studied regulating TEPS, specify their construction, and the geometric and mechanical requirements that must be met. However, the format of verification of the mechanical requirements varies significantly among the different documents consulted and gives rise to very different solutions (16-18).

It seems appropriate to limit the maximum displacement of a system under a certain load value. This limitation is 
limitación tiene como objetivo impedir el basculamiento del trabajador sobre el SPPB en caso de tropiezo e impacto sobre él: cuanto mayor sea el desplazamiento del SPPB, más fácil es que el trabajador lo sobrepase. Sin embargo, en la posibilidad de voltear sobre el SPPB influye de manera decisiva el desplazamiento vertical del sistema, tanto o más que el desplazamiento horizontal. Se puede afirmar que más que el desplazamiento vertical del sistema, lo decisivo es la altura a la que quedaría el sistema después del impacto. En este sentido la normativa norteamericana especifica en la comprobación de desplazamiento que ningún punto del sistema, después de aplicar una carga vertical de $890 \mathrm{~N}$, debe quedar a menos de 1,00 m de altura respecto del plano del forjado (19).

Los SPPB ensayados en este trabajo solamente experimentan desplazamientos horizontales, su enorme rigidez en el plano vertical hace que los desplazamientos en esta dirección sean prácticamente nulos. Este tipo de sistemas ofrece una seguridad frente al basculamiento superior a la de sistemas fabricados con barandillas de tubo de acero o Tablas de madera, en los cuales se produciría un desplazamiento que tendría una componente vertical y otra horizontal en el caso de entrar en carga.

\section{CONCLUSIONES}

La adición de fibras de vidrio a matrices de PEAD da lugar a un material compuesto con un módulo de elasticidad longitudinal muy superior al del material base y unos valores de coeficiente de fluencia muy inferiores a los del material original.

Los SPPB PEAD+FV ensayados superan los requisitos de carga estática de la norma UNE-EN 13374.

Los SPPB fabricados con PEAD o PEAD+FV ensayados superan los requisitos de resistencia y de carga accidental especificados por la norma UNE-EN 13374.

Los SPPB fabricados con PEAD o PEAD+FV ensayados superan los requisitos de la norma UNE-EN 13374 frente a carga de impacto.

Se han obtenido en los sistemas fabricados con PEAD flechas diferidas de valores muy altos incluso para cargas muy pequeñas mantenidas únicamente durante 1 minuto. La relación entre la flecha diferida y la flecha instantánea no aumenta con el nivel de carga.

No se aprecia ninguna relación entre el envejecimiento natural y el comportamiento de SPPB PEAD, tanto a carga estática como a carga de impacto. intended to prevent the worker from tipping over the TEPS if the person stumbles and impacts on it: the greater the displacement of the TEPS, the easier for the worker to tip over it. However, the vertical displacement of the system influences decisively the possibility of tipping over TEPS, even more than the horizontal displacement. It can be said that more than the vertical displacement of the system, the decisive factor is the height to which the system is after the impact. Regarding this, American standards specify that in the displacement verification, no point of the system should be lower than $1.00 \mathrm{~m}$ in relation to the slab plane (19), after having applied a vertical load of $890 \mathrm{~N}$.

The tested TEPS in this work, experience only a horizontal displacement. Their enormous rigidity in the vertical plane make the displacement in this direction to be virtually non-existent. This type of systems provide a higher safety against tipping over than the systems manufactured with steel tube railings or wooden planks, in which there would be a displacement that would have another horizontal and a vertical component when applying a load.

\section{CONCLUSIONS}

The addition of glass fibers to HDPE matrixes gives rise to a composite with a longitudinal elasticity modulus much higher than the base material, and with much lower yield coefficient values than the original material.

The tested HDPE+GF TEPS meet the requirements of static load stated in the UNE-EN 13374 standard.

TEPS made of HDPE or HDPE+GF tested meet the strength and accidental load requirements specified in the UNEEN 13374 standard.

TEPS made of HDPE or HDPE+GF tested fulfil the requirements of the UNE-EN 13374 standard regarding impact loads.

High values of deferred deflections have been obtained even for very small loads maintained for only one minute, with the HDPE systems. The relationship between deferred deflection and instantaneous deflection does not increase with the load level.

No relationship is observed between natural ageing and the behaviour of HDPE TEPS, neither with static loads nor with impact loads. 
Los ensayos de flexión estática y dinámica, sobre probetas del mismo material que los SPPB PEAD, envejecidas aceleradamente, no muestran una dependencia de su comportamiento con el grado de envejecimiento.

Los SPPB formados por una valla continua ofrecen, para el mismo desplazamiento horizontal, una seguridad frente al basculamiento superior a la de SPPB fabricados con barandillas que pueden experimentar desplazamientos verticales.
Static and dynamic bending tests, on samples of the same material as the HDPE TEPS, under accelerated aging, does not show an influence on their behaviour regarding the ageing degree.

When the same horizontal displacement occurs, TEPS made of a continuous mesh, show a higher tipping-over safety than TEPS manufactured with railings, which can suffer vertical displacements.

\section{BIBLIOGRAFÍA / BIBLIOGRAPHY}

(1) Johnston N.J.; Towell, T.W.; Hergenrother, P.M.: Physical and mechanical properties of high-performance thermoplastics polymers and their composites, pp. 27-71. In: Carlsson L.A. (ed.). Thermoplastic composite materials. Elsevier Science Publishers B.V. Amsterdam (1992).

(2) Peacock, A.J.: Handbook of polyethylene. Structures, properties and application, Marcel Dekker, Inc. New York (2000).

(3) Antequera, P.; Jiménez L.; Miravete, A.: Los materiales compuestos de fibra de vidrio, Secretariado de Publicaciones Ciudad Universitaria Geológicas, Zaragoza (1991).

(4) Kim, H.C.; Glenn, L.W.; Ellis, C.S.; Miller, D.E.: "Selecting long-glass fibre/thermoplastics for creep resistance". Plast. Eng. vol. 53, no 1 (1997), pp. 39-40.

(5) Markarian, J.: "Long fibre reinforced thermoplastics continue growth in automotive". Plast. Addit. Compound, vol. 9, no 2 (2007), pp. 20-24.http://dx.doi.org/10.1016/S1464-391X(07)70025-9

(6) Osswald, T.A.; Baur, E.; Brinkmann, S.; Oberbach, K.; Schmachtenberg, E.: International plastics handbook: the resource for plastics engineers. 4th ed.; Hanser, Cincinnati (2006).

(7) Nguyen, B.N., et al:: "Fiber length and orientation in long-fiber injection-molded thermoplastics. Part I: Modeling of microstructure and elastic properties", J. Compos. Mater., vol. 42, no 10 (2008), pp. 1003-1029.http://dx.doi.org/10.1177/0021998308088606

(8) Yang, S.W.; Chin, W.K.: "Mechanical properties of aligned long glass fiber reinforced polypropylene. I: Tensile strength", Polym. Compos., vol. 20, no 2 (1999), pp. 200-206.http://dx.doi.org/10.1002/pc.10347

(9) Houshyar, S.; Shanks, R.A.; Hodzic, A.: "Tensile creep behaviour of polypropylene fibre reinforced polypropylene composites", Polym Test., vol. 24, no 2 (2005), pp. 257-264.http://dx.doi.org/10.1016/j.polymertesting.2004.07.003

(10) Bartus, S.D.; Vaidya, U.K.: "Performance of long fiber reinforced thermoplastics subjected to transverse intermediate velocity blunt object impact", Compos. Struct., vol. 67, no 3 (2005), pp. 263-277.http://dx.doi.org/10.1016/j.compstruct.2004.07.023

(11) AENOR-CEN. UNE-EN 13374. Sistemas provisionales de protección de borde. Especificaciones del producto, métodos de ensayo, Asociación Española de Normalización AENOR (2004).

(12) UNE-EN 596. Estructuras de madera. Métodos de ensayo. Ensayo de choque por cuerpo blando sobre muros entramados de madera, Asociación Española de Normalización AENOR (1996).

(13) UNE-EN ISO 4892-2. Plásticos. Métodos de exposición a fuentes luminosas de laboratorio. Parte 2: Lámparas de xenón, Asociación Española de Normalización AENOR (2006).

(14) UNE-EN ISO 178. Plásticos. Determinación de las propiedades de flexión, Asociación Española de Normalización AENOR (2003).

(15) UNE-EN ISO 179-1. Plásticos. Determinación de las propiedades al impacto Charpy. Parte 1: Ensayo de impacto no instrumentado, Asociación Española de Normalización AENOR (2001).

(16) Cobo, A.; González, M.N.: "Study of temporary edge protection systems using different standars". 3th IAHS World Congress on Housing Science. Design, Technology, Refurbishment and Management of Buildings, Santander (2010).

(17) González, M.N.: "Consideraciones respecto a los sistemas provisionales de protección de borde", Tesis Doctoral, Universidad Politécnica de Madrid, España (2010).

(18) González, M.N.; Cobo, A.; Fuente, J.V.; Bresó, S.; Lozano, C.: "Comportamiento bajo cargas estáticas de sistemas provisionales de protección de borde realizados con elementos de acero", Inf. Constr., vol. 63, no 521 (2011), pp. 57-67. doi: 10.3989/ic.09.070.

(19) OSHA. Part 1926. Subpart M CFR 1926.500 - Fall Protection for the Construction Industry, Occupational Safety \& Health Administration, US Department of Labor, Washington, D.C.; (1998). 